\title{
Particulate matter air pollution causes oxidant- mediated increase in gut permeability in mice
}

\author{
Ece A Mutlu*, Phillip A Engen ${ }^{1}$, Saul Soberanes ${ }^{2}$, Daniela Urich², Christopher B Forsyth ${ }^{1}$, Recep Nigdelioglu², \\ Sergio E Chiarella², Kathryn A Radigan², Angel Gonzalez², Shriram Jakate ${ }^{3}$ Ali Keshavarzian', GR Scott Budinger ${ }^{2}$ \\ and Gökhan M Mutlu²
}

\begin{abstract}
Background: Exposure to particulate matter (PM) air pollution may be an important environmental factor leading to exacerbations of inflammatory illnesses in the Gl tract. PM can gain access to the gastrointestinal (GI) tract via swallowing of air or secretions from the upper airways or mucociliary clearance of inhaled particles.

Methods: We measured PM-induced cell death and mitochondrial ROS generation in Caco-2 cells stably expressing oxidant sensitive GFP localized to mitochondria in the absence or presence of an antioxidant. C57BL/6 mice were exposed to a very high dose of urban PM from Washington, DC (200 $\mu \mathrm{g} / \mathrm{mouse})$ or saline via gastric gavage and small bowel and colonic tissue were harvested for histologic evaluation, and RNA isolation up to 48 hours. Permeability to $4 \mathrm{kD}$ dextran was measured at 48 hours.

Results: PM induced mitochondrial ROS generation and cell death in Caco-2 cells. PM also caused oxidantdependent NF- $\kappa$ B activation, disruption of tight junctions and increased permeability of Caco-2 monolayers. Mice exposed to PM had increased intestinal permeability compared with PBS treated mice. In the small bowel, colocalization of the tight junction protein, ZO-1 was lower in the PM treated animals. In the small bowel and colon, PM exposed mice had higher levels of IL-6 mRNA and reduced levels of ZO-1 mRNA. Increased apoptosis was observed in the colon of PM exposed mice.
\end{abstract}

Conclusions: Exposure to high doses of urban PM causes oxidant dependent Gl epithelial cell death, disruption of tight junction proteins, inflammation and increased permeability in the gut in vitro and in vivo. These PM-induced changes may contribute to exacerbations of inflammatory disorders of the gut.

\section{Background}

In human populations, investigators have associated PM exposure with an increasing number of adverse health outcomes including all-cause mortality, cardiovascular mortality, accelerated atherosclerosis in postmenopausal women, loss of lung function in healthy adults, impaired lung development in children, exacerbations of obstructive lung disease, pneumonia and increased risk of venous thromboembolism [1-11]. Recently, Kaplan et al reported that individuals younger than 23 years were more likely to be diagnosed with Crohn's disease if they lived in regions with higher $\mathrm{NO}_{2}$ concentrations [12], a

\footnotetext{
* Correspondence: Ece_Mutlu@rush.edu

'Department of Medicine, Section of Gastroenterology and Nutrition Rush University Medical College, 1725 W Harrison Street, Chicago, IL, 60612 USA Full list of author information is available at the end of the article
}

marker of traffic related pollution that correlates with the levels of PM and an independent group of investigators reported that exposure to PM was associated with hospitalizations in patients with inflammatory bowel disease [13]. PM exposure has also been reported to increase the risk of appendicitis,[14] the development of gastroenteritis in children [15] and colorectal cancer [16-19].

Many of the adverse health consequences of PM are thought to be caused by the ability of PM to induce cellular oxidative stress, which activates signaling pathways that contribute to cytokine release and barrier dysfunction [20]. As the bulk of PM enters the body by inhalation, investigators have used radiolabeled particles to examine the fate of inhaled particles in rodents [21]. They found that the overwhelming majority of the

\section{Biomed Central}


particles (> 95\%) are taken up by alveolar macrophages, brought to the oropharynx by mucociliary clearance and excreted in the feces [21].

PM may also enter the GI tract directly through swallowed air or through the ingestion of foods such as vegetables and fruits coated with PM. These findings suggest that the steady state concentrations of PM in the GI tract may be similar to those encountered in the lung. In this paper, we sought to test the hypothesis that PM exposure can induce oxidant dependent epithelial dysfunction of the GI tract in mice. We tested our hypothesis in cell based systems and in mice using a very high dose of a well characterized urban PM.

\section{Methods}

\section{Particulate Matter (PM)}

We used an urban PM collected from ambient air in Washington, DC (National Institute of Standards and Technology Standard Reference Material, SRM 1649a). The characteristics of PM have been previously described [22,23].

\section{Animals and administration of PM via gavage}

The protocol for the use of mice was approved by the Animal Care and Use Committee at Northwestern University and Rush University in Chicago, IL. We used eight to twelve weeks old, (20-25 g), male, C57BL/6 mice (Jackson Laboratories). Mice were anesthetized with isoflurane $2-3 \%$. After adequate anesthesia is achieved, the esophagus was intubated using a mouse gastric gavage tube and $200 \mu \mathrm{g}$ of PM suspended in sterile PBS or PBS only (control) was administered via gavage tube followed by $100 \mu \mathrm{l}$ of air to clear the liquid in the gavage tube. Particulate matter does not dispersed well in aqueous solutions because it forms aggregates in PBS or in culture media within several minutes. Therefore, PM in PBS was vortexed immediately prior to instillation [24]. After treatment, the gavage tube was removed gently and the animals were placed in their cages until harvesting of stomach, small bowel and colon at 24 and 48 hours. Permeability experiments were also performed at 48 hours.

\section{Histology}

At 24 or 48 hours after treatment with PM, mice were euthanized for collection of stomach, small bowel and colon tissue. After harvesting, the tissues were fixed and paraffin embedded and 5- $\mu \mathrm{m}$ sections were stained with hematoxylin/eosin.

\section{TUNEL staining of colonic sections}

End labeling of exposed 3'-OH ends of DNA fragments in paraffin-embedded tissue was done utilizing the TUNEL AP In Situ Cell Death Detection Kit (Roche
Diagnostics Corp.) according to the manufacturer's directions. After staining, 20 fields of colonic sections (400x) were randomly chosen and nuclei and total nuclei were counted using an automated program (Image J) [25].

\section{Assessment of intestinal permeability in mice}

GI permeability was measured based on the intestinal permeability towards 4000Da-fluorescent-dextran- FITC (DX-4000-FITC) (FD4000 Sigma-Aldrich, St. Louis, Mo, USA) as described [26,27]. Briefly, mice were given DX4000 -FITC by gavage $(500 \mathrm{mg} / \mathrm{kg}$ body-weight, $125 \mathrm{mg}$ / $\mathrm{ml}$ ). After 1 hour, $120 \mu \mathrm{l}$ of blood were collected via right atrial puncture. The blood was centrifuged at $4^{\circ} \mathrm{C}$, $12000 \times \mathrm{g}$ for $3 \mathrm{~min}$. Plasma was diluted in an equal volume of PBS ( $\mathrm{pH} 7.4$ ) and analyzed for DX-4000FITC concentration with a fluorescence spectrophotometer at the excitation wavelength of $485 \mathrm{~nm}$ and the emission wavelength of $535 \mathrm{~nm}$. Standard curves were obtained by diluting FITC-dextran in non-treated plasma diluted with PBS (1:3 v/v).

\section{Cell culture}

Caco-2 cells (a human colon adenocarcinoma cell line) (American Type Culture Collection, Manassas, VA) were chosen for our studies because they form monolayers that morphologically resemble intestinal cells with defined apical brush borders. Cells were cultured in Dulbecco's minimum essential medium at $37^{\circ} \mathrm{C}, 5 \%$ $\mathrm{CO}_{2}, 100 \%$ relative humidity. Cells were exposed to PM diluted in media or control vehicle (media). To ensure equal dispersion, the PM solution was vortexed with the media before application to the cells. For barrier function experiments, Caco- 2 cells were split at a ratio of $1: 2$ and seeded at a density of 200,000 cells $/ \mathrm{cm}^{2}$ into 0.4 $\mu \mathrm{M}$ Biocoat Collagen I Cell Culture Inserts $\left(0.3 \mathrm{~cm}^{2}\right.$ growth surface; Becton Dickinson Labware, Bedford, MA) and experiments were performed at least 3 weeks post-confluence. The confluence of Caco- 2 monolayers was confirmed with transepithelial electrical resistance (TEER) measurements as described below [28,29]. Only monolayers of cells with TEER values greater than 250 $\Omega \times \mathrm{cm}^{2}$ (after subtraction of the bare filter inserts [100-150 $\left.\Omega \times \mathrm{cm}^{2}\right]$ ) were used for the experiments as previously described by Turner et al and other investigators [28,30-33]. The confluent monolayers were exposed to PM suspended in media or vehicle control (media alone). To ensure equal dispersion, the PM solution was vortexed with the media before application to the cells.

Measurement of transepithelial electrical resistance (TEER) Transepithelial electrical resistance (TEER) was determined in polarized Caco-2 cell monolayers, cultured in 6-well plates, using a Millicell-ERS Resistance System (Millipore, Bedford, MA) that includes a dual electrode 
volt-ohm-meter. TEER was calculated as TEER $=\left(R_{\mathrm{m}^{-}}\right.$ $\left.R_{\mathrm{i}}\right) \times A$, where $R_{\mathrm{m}}$ is transmembrane resistance; $R_{\mathrm{i}}$, intrinsic resistance of a cell-free media; and $A$, the surface area of the membrane in $\mathrm{cm}^{2}[28,29,34]$. The TEER measurements were performed in serum free media.

\section{Measurement of the apparent permeability coefficient (Papp) of fluorescein sulfonic acid (FSA)}

Barrier permeability was determined using Caco-2 cells grown to confluence on $6.5-\mathrm{mm} / 0.4 \mu \mathrm{m}$ 24-well tissue culture plate inserts (Transwell, Corning) as we have previously described $[35,36]$. The measurements were performed in serum free media. Permeability of insert Caco-2 monolayers was evaluated by measurements of the apparent permeability coefficient (Papp) of the fluorescent marker fluorescein-5-(and-6)-sulfonic acid trisodium salt (FSA, $200 \mu \mathrm{g} / \mathrm{ml}, 478 \mathrm{Da}$ ) (Invitrogen) in the apical to basolateral direction [33]. Fluorescent signals from samples were measured using a fluorescence multiplate reader (FSA excitation, $485 \mathrm{~nm}$; FSA emission, $530 \mathrm{~nm})$. The Papp was calculated by the following formula: Papp $(\mathrm{cm} / \mathrm{sec})=(\mathrm{dQ} / \mathrm{dt}) /(\mathrm{Co} \times \mathrm{A})$, where $\mathrm{dQ} / \mathrm{dt}$ is the permeability rate $(\mathrm{mol} / \mathrm{s})$; $\mathrm{Co}$ is the initial concentration in the donor compartment $(\mathrm{mol} / \mathrm{ml})$ and $\mathrm{A}$ is the surface area of the monolayer $\left(0.33 \mathrm{~cm}^{2}\right)$.

\section{Assessment of cell death}

Cell death was assessed using a commercially available photometric immunoassay that detects histone-associated DNA fragments (Roche Diagnostics, Indianapolis, IN) according to the manufacturer's directions, as we have previously described [37].

\section{Generation of Caco-2 cells stably expressing mitochondrially localized oxidant sensitive GFP (mito-Ro- GFP) probes}

An adenoviral vector encoding Ro-GFP with a mitochondrial localization sequence (mito-Ro-GFP) was generated as described previously and commercially amplified (ViraQuest, Iowa City, IA) [37,38]. A lentiviral vector encoding the mito-Ro-GFP probe with a mitochondrial localization sequence was created using the ViraPower lentiviral transformation kit according to the manufacturer's directions (Invitrogen) as previously described [37]. Expression of the probe was confirmed by examining the cells using fluorescence microscopy. Appropriate localization of the probe to the mitochondria was confirmed by co-staining with the mitochondrial probe MitoTracker $(10 \mu \mathrm{M})$ (Invitrogen, Carlsbad, CA).

Generation of Caco-2 cells lacking mitochondrial DNA ( $\rho^{0}$ Caco-2 cells)

The $\rho^{0}$ Caco- 2 cells were generated by incubating Caco2 cells in medium containing ethidium bromide $(100$ $\mathrm{ng} / \mathrm{ml})$, sodium pyruvate $(1 \mathrm{~mm})$, and uridine $(100 \mu \mathrm{g} /$ $\mathrm{ml}$ ) for 3-5 weeks. The lack of DNA encoding cytochrome oxidase subunit IV was confirmed by PCR using the primer sequences described previously $[37,39,40]$. Cells depleted of mitochondrial DNA, or $\rho^{0}$ cells, lack 13 proteins critical for normal electron transport. Although $\rho^{0}$ cells contain petite mitochondria, they cannot support normal oxidative phosphorylation and must survive and replicate using ATP derived solely from glycolysis. Without a functional electron transport chain, $\rho^{0}$ cells cannot generate ATP from electron transport and their mitochondria are incapable of generating reactive oxygen species $[40,41]$.

\section{Measurement of Reactive Oxygen Species}

We employed an oxidant-sensitive ratiometric probe (Ro-GFP) that was originally described by Hanson and co-workers who validated its responsiveness to a variety of intracellular oxidants both ex vivo and in living cells $[42,43]$. We generated Caco- 2 cells stably expressing the mito-Ro-GFP probe and measured the oxidation state of the probe using flow cytometry as we have previously described [37]. Briefly, the cells were removed from the plate using trypsin, and equal aliquots of the resulting suspension were transferred to tubes containing medium alone or medium containing $1 \mathrm{mM}$ dithiothreitol or $1 \mathrm{mM} t$-butyl hydroperoxide (t-BOOH). After 10 $\mathrm{min}$, the ratio of fluorescence (emission of $535 \mathrm{~nm}$ ) at excitations of 405 and $488 \mathrm{~nm}$ was measured in 5,000 cells/condition using a DakoCytomation CyAn high speed multilaser droplet cell sorter. The oxidation state of the cells was calculated as follows: (value after treatment - value after dithiothreitol (completely reduced state))/(value after t-BOOH (completely oxided state) value after dithiothreitol (completely reduced state)) $[37,38]$. In some experiments, we also treated cells with EUK-134 (20 $\mu \mathrm{M})$ (Cayman Chemicals, Ann Arbor, $\mathrm{MI}$ ), which is a combined superoxide dismutase and catalase mimetic that has been shown to prolong the lifespan of the nematode Caenorhabditis elegans and to prevent alveolar epithelial cell death during injurious stimuli $[44,45]$.

\section{Immunoblotting determination of nitration and oxidation of tubulin to assess cytoskeleton}

Oxidation and nitration of the tubulin backbone of microtubules were assessed by measuring protein carbonyl and nitrotyrosine formation, respectively [46]. Carbonylation and nitrotyrosination of tubulin were determined in a similar manner as the quantitative blotting of tubulin. To avoid unwanted oxidation of tubulin samples, all buffers contained $0.5 \mathrm{mM}$ dithiothreitol and $20 \mathrm{mM}$ 4,5-dihydroxy-1,3-benzene sulfonic acid (Sigma). 
Immunofluorescent staining and high-resolution laser scanning confocal microscopy of the actin cytoskeleton Integrity of actin cytoskeleton integrity in monolayers of Caco-2 cells was determined as previously described [47]. Cells were subsequently processed by incubation with fluorescein isothiocyanate (FITC)-conjugated phalloidin (specific for F-actin staining, Sigma, St. Louis, $\mathrm{MO}), 1: 40$ dilution for $1 \mathrm{~h}$ at $37^{\circ} \mathrm{C}$. Desired areas of monolayers were processed using the image processing with Zeiss Axiovision and NIH Image J software.

\section{Analysis of NF- $\kappa \mathrm{B}$ activation}

NF- $\kappa$ B (p65 and p50 subunit) activation was assessed by ELISA as we have previously described [35,48]. The NF$\kappa \mathrm{B}$ activity test is based on a validated ELISA principle in which NF- $\kappa \mathrm{B}$ is captured by a double stranded oligonucleotide probe containing the consensus-binding sequence for either NF- $\kappa \mathrm{B}$ p 65 or p50 subunits [49]. The results were quantified by a chromogenic reaction, which was then read for absorbance at $450 \mathrm{~nm}$ by a Seivers NOA 280 microplate analyzer (Sievers, CO) [49].

Immunofluorescence staining of zonula occludens-1 (ZO1) and occludin for tight junction morphology

Immunofluorescence staining for ZO-1 and occludin was performed in Caco- 2 cells and fresh frozen mouse small bowel tissue sections using primary anti-ZO-1 antibody (Zymed) (1:200 dilution) or for anti-occludin antibody (Zymed) (1:100 dilution) for 1 hour at $37^{\circ} \mathrm{C}$ followed by incubation with a secondary antibody (fluorescein isothiocyanate-conjugated goat anti-mouse; SigmaAldrich, St. Louis, MO; 1:50 dilution) for 1 hour at room temperature. Imaged areas of monolayers were processed using Zeiss Axiovision and NIH Image J image processing software.

\section{Evaluation of tight junction disruption}

Caco-2 cells were stained for ZO-1 and the slides were examined for their overall morphology, orientation, and disruption as we previously described $[35,50]$. To avoid bias, the slides were coded so that the examiner was blinded to the experimental protocol. After the scoring was complete, the slides were decoded for analysis. Briefly, the "ZO-1 integrity" in Caco-2 cells was considered abnormal or injured based on one or more of the following criteria: fragmentation, kinking, disruption of actin cortex, or detachment from membrane areas (areas of cell-to-cell contact). We examined 200 cells per slide (well) by LSCM microscopy, and the percentage (\%) of cells displaying normal ZO-1 or abnormal $\mathrm{ZO}-1$ was determined (e.g., 90 cells [displaying injured $\mathrm{ZO}-1$ ] divided by 200 is equal to $45 \%$ abnormal $\mathrm{ZO}-1$ or $55 \%$ normal ZO-1). Overall, at least 1,200 cells per group $(200 \times 6$ slides $)$ were examined in four different fields by LSCM and the percentage of cells displaying normal ZO-1 was then determined per treatment group.

\section{Statistics}

Differences between groups were explored using analysis of variance. When the analysis of variance indicated a significant difference, individual differences were explored using $t$ tests with a Dunnett correction for multiple comparisons against control conditions. All of the analyses were performed using GraphPad Prism version 4.00 for Windows (GraphPad Software, San Diego, CA).

\section{Results}

Particulate matter induces a dose-dependent ROS generation and cell death in colonic epithelial cells

We previously reported that exposure of alveolar epithelial cells to $\mathrm{PM}_{10}$ collected from Düsseldorf, Germany induced the generation of ROS [51]. To determine whether PM can induce ROS generation in the GI tract epithelia, we treated Caco- 2 cells stably expressing mitochondrial oxidant sensitive GFP (mito-Ro-GFP) with vehicle (media) or different concentrations of urban PM from Washington, D.C. Four hours later, we assessed PM-induced ROS production by measuring the oxidation of the probe. Treatment with $t$-butyl hydroperoxide was used as a positive control. Exposure of Caco- 2 cells to PM caused a dose-dependent ROS generation from the mitochondria (Figure 1A). To determine whether PM can induce cell death in the GI tract epithelia, we treated Caco-2 cells with vehicle (media) or different concentrations of PM for 24 hours and measured apoptotic cell death (DNA fragmentation). Exposure of Caco-2 cells to PM caused a dose-dependent increase in the percentage of TUNEL positive cells (Figure 1B).

\section{The generation of mitochondrial ROS is required for PM-} induced cell death in colonic epithelial cells

We treated Caco-2 cells stably expressing mitochondrial oxidant sensitive GFP (mito-Ro-GFP) with vehicle (media) or different concentrations of PM from Washington, D.C in the absence or presence of the combined superoxide dismutase and catalase mimetic, EUK -134 $(20 \mu \mathrm{M})$, which was added to the media 1 hour before exposure. We then measured oxidation of the mitochondrially localized probe 4 hours later and apoptotic cell death 24 hours later. Both PM-induced ROS generation and cell death were attenuated in cells treated with (EUK-134) therapy (Figure 2A,B).

To determine whether mitochondrially generated ROS are required for PM-induced cell death, we generated Caco- 2 cells lacking mitochondrial DNA ( $\rho^{0}$ Caco- 2 cells). Wild type and $\rho^{0}$ Caco- 2 cells were infected with an adenovirus encoding the mito-Ro-GFP, and the 

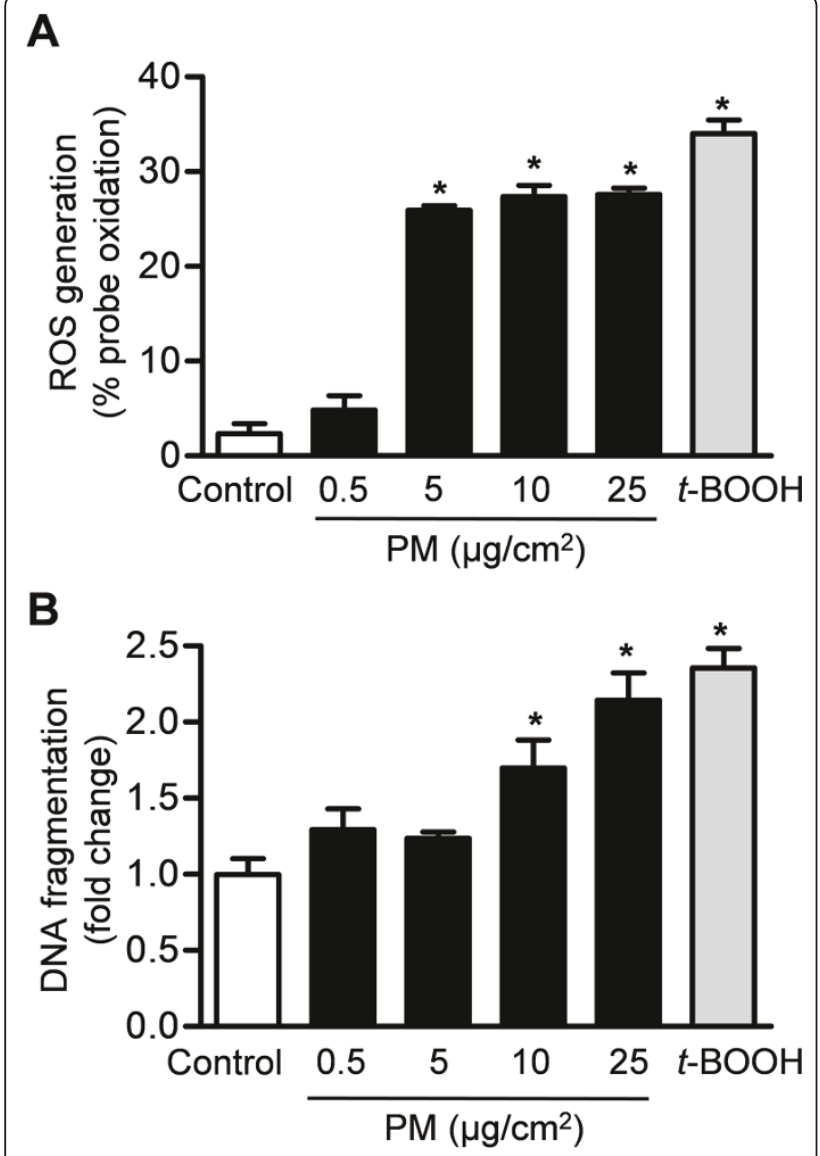

Figure 1 Particulate matter induces dose-dependent ROS generation and cell death in colonic epithelial cells. (A) Caco-2 cells stably expressing an oxidant-sensitive GFP probe (mito-Ro-GFP, lentivirus) were treated with control vehicle (media) or different doses of PM. The percentage oxidation of the probe was measured using flow cytometry 4 hours later. The $t$-butyl hydroperoxide ( $t$ $\mathrm{BOOH}$ ) was used as a positive control. (B) Caco-2 cells were treated as described above and cell death (DNA fragmentation via enzymelinked immunosorbent assay) was measured 24 hours later. ( ${ }^{*} P<$ 0.05 PM compared with PBS, $n \geq 4$ ).

oxidation of the probe was measured at 4 hours after treatment with PM $\left(25 \mu \mathrm{g} / \mathrm{cm}^{2}\right)$ suspended in media or control vehicle (media) using flow cytometry. Compared to wild-type cells, $\rho^{0}$ Caco- 2 cells produced minimal ROS in response to PM (Figure 2C). We treated wildtype and $\rho^{0}$ Caco- 2 cells with PM and measured cell death 24 hours later. Compared with wild-type cells, PM-induced cell death was attenuated in the $\rho^{0} \mathrm{Caco}-2$ cells (Figure 2D).

\section{Exposure to PM causes oxidant-dependent NF- $\kappa$ B activation and increased permeability in Caco-2 cell monolayers}

As oxidant stress in the gut oxidation has been associated with activation of the nuclear transcription factor,
$\mathrm{NF}-\kappa \mathrm{B}$ [52], we measured NF- $\kappa \mathrm{B}$ in Caco-2 cells exposed to either PM or vehicle (PBS). Exposure to PM caused a dose-dependent increase in NF- $\kappa \mathrm{B}$ activity, which was prevented by, EUK-134 (Figure 3A).

Intestinal barrier disruption has been implicated in several intestinal and systemic disorders and has been associated with ROS generation, NF- $\kappa \mathrm{B}$ activation and cell death $[50,53]$. We treated Caco-2 cells with either vehicle (media) or different concentrations of PM and assessed the permeability of the monolayer by measuring the transepithelial electrical resistance (TEER) (Figure 3B) and the apparent permeability coefficient (Papp) of fluorescein sulfonic acid (FSA) in the apical to basolateral direction (Figure $3 \mathrm{C}$ and 3D). Exposure to PM caused an increase in permeability (Figure 3 ).

Exposure to particulate matter causes nitration and oxidation injury and disruption of the microtubule cytoskeleton of intestinal cell monolayers

We assessed the effect of PM induced ROS generation on the cytoskeleton by measuring the amount of nitration (nitrotyrosination) and oxidation (carbonylation) of tubulin in Caco-2 cells as previously described [46]. Oxidant $\left(\mathrm{H}_{2} \mathrm{O}_{2}, 0.5 \mathrm{mM}\right)$ alone resulted in substantial levels of nitration (nitro and oxidation of the tubulin cytoskeleton (Figure 4A and 4B)). Exposure to Caco-2 cells to PM caused nitration and oxidation of the tubulin cytoskeleton, which was evident even at the lowest dose of PM $\left(0.5 \mu \mathrm{g} / \mathrm{cm}^{2}\right)$. High-resolution laser scanning confocal microscopic evaluation of Caco-2 monolayers confirmed that intestinal cells exhibited abnormal architecture of the microtubule cytoskeleton after treatment with PM. The changes seen at highest dose of PM $\left(50 \mu \mathrm{g} / \mathrm{cm}^{2}\right)$ were similar to those seen from cell monolayers that are challenged with $\mathrm{H}_{2} \mathrm{O}_{2}$ (Figure 4C).

\section{Exposure of Caco-2 cells to particulate matter causes disruption of tight junctions}

To determine whether PM-induced increased permeability in monolayers of Caco-2 cells is associated with changes in their tight junctions, we stained monolayers of Caco-2 cells for ZO-1, a tight junction protein. Caco2 cells exposed to PM had discontinuity and irregularity of ZO-1 distribution at the intercellular junctions suggesting the loss of tension in intestinal cells. ZO-1 was rearranged from an uninterrupted band along cell borders into radially oriented sporadic aggregates (Figure $5 \mathrm{~A})$. The severity of tight junction disruption estimated from blinded analysis of ZO-1 stained sections for their overall morphology, orientation, and disruption was increased in PM compared with control treated Caco-2 cells (Figure 5B). 


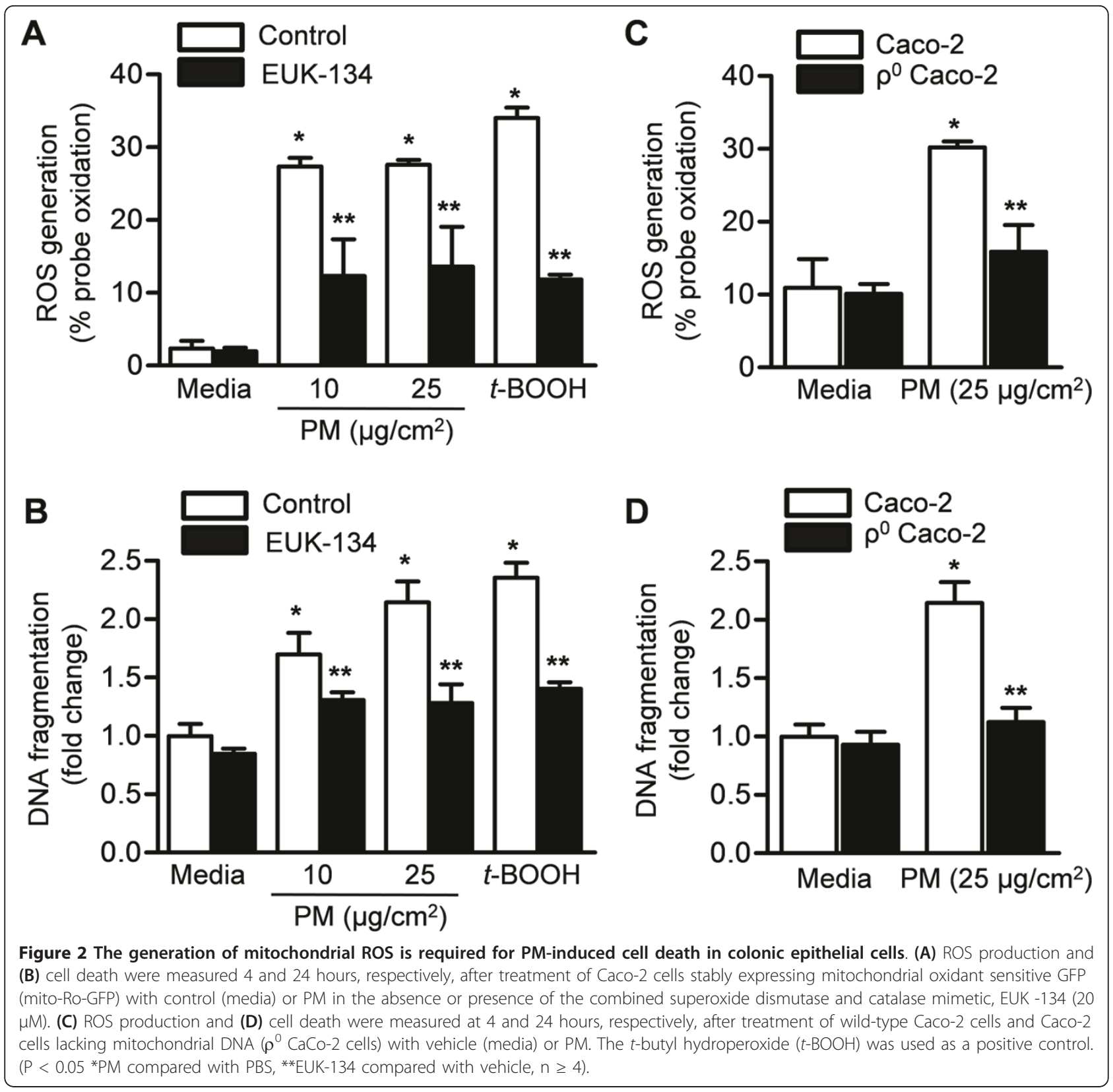

Exposure to PM causes increased gut permeability and inflammation and colonic epithelial cell death in mice To determine whether PM exposure affects GI epithelia in vivo, we treated mice with PM administered via gavage and harvested the stomach and colon 48 hours later. Exposure to PM did not cause any detectable histologic changes in the GI tract (Figure 6). However, compared to PBS treated animals, mice exposed to PM exhibited an increase in IL- 6 mRNA in the small bowel and colon suggesting that PM induces an inflammatory response in the gut (Figure $7 \mathrm{~A}$ ).

We measured the permeability of the gut permeability to a $4 \mathrm{kD}$ dextran (Figure 7B) 48 hours after the administration of $\mathrm{PM}$ or $\mathrm{PBS}$ via gavage. PM exposure was associated with a significant increase in permeability. We then counted the number of TUNEL-positive nuclei observed in colonic sections obtained 48 hours after treatment with PM or PBS. Treatment with PM was associated with an increase in the number of TUNEL positive nuclei (Figure 7C). Forty-eight hours after treatment with $\mathrm{PM}$, we observed a significant reduction in the mRNA encoding $\mathrm{ZO}-1$ measured by qRT-PCR in the small bowel and colon (Figure 7D). The ZO-1 protein expression in the small bowel did not change significantly after PM treatment (Figure 7E). Examination of ZO-1 and occludin stained sections of 

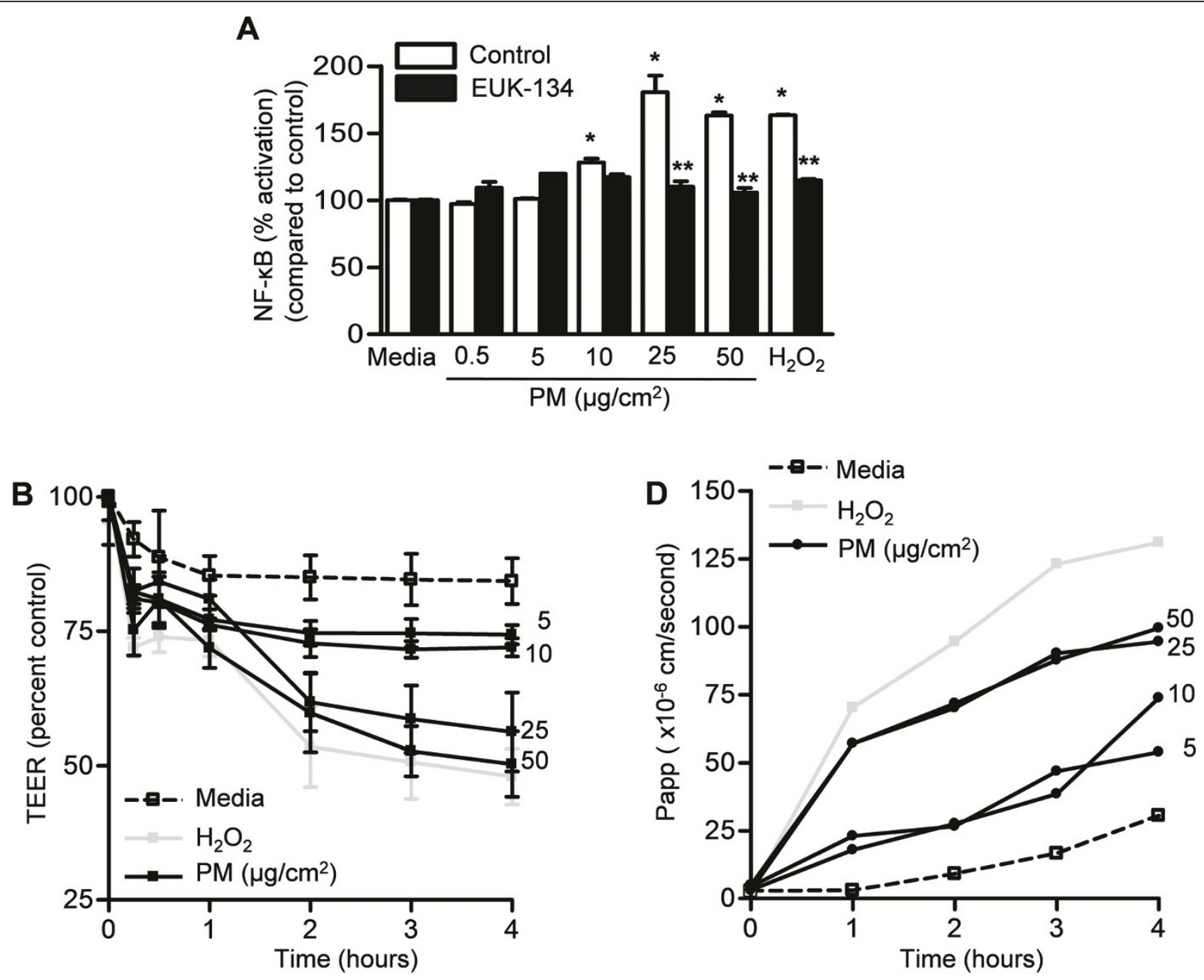

C
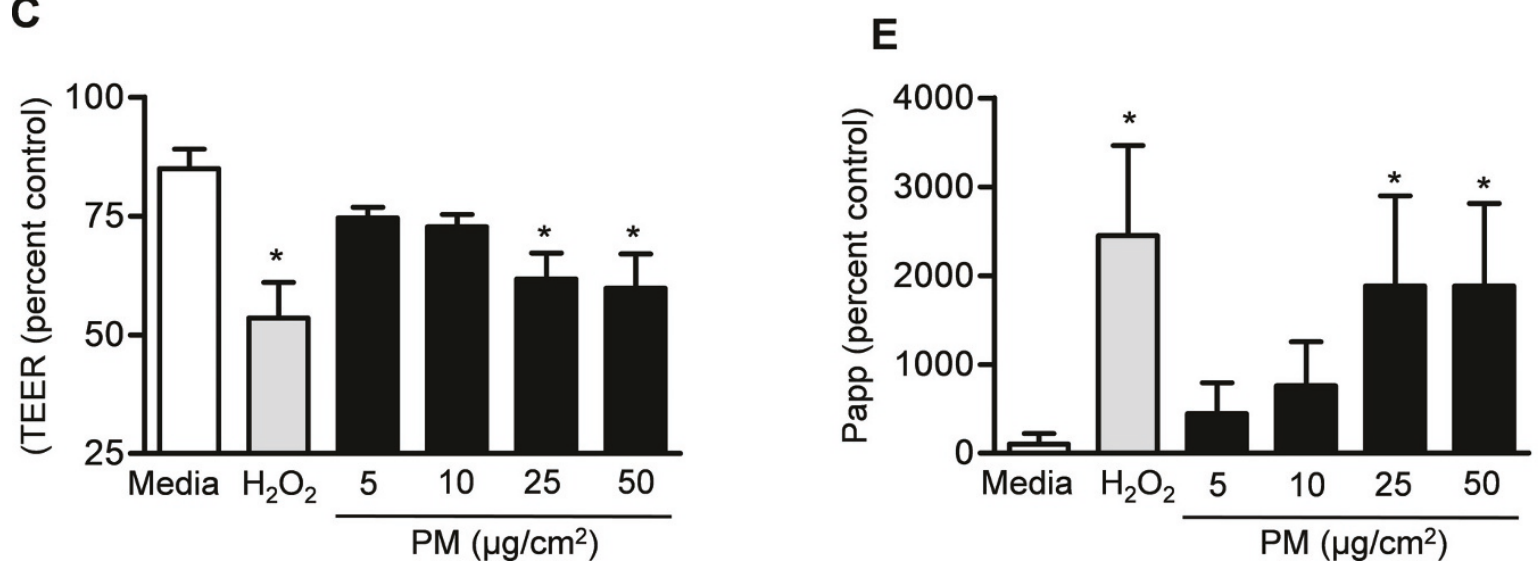

Figure 3 Exposure of Caco-2 cells to PM causes oxidant-dependent NF- $\kappa$ B activation and increased permeability. (A) NF- $\kappa$ B activation was measured in Caco-2 cells treated with vehicle (PBS) or different doses of PM in the absence or the presence of the combined superoxide dismutase and catalase mimetic, EUK -134 (20 $\mu \mathrm{M})$. NF- $\kappa$ B activation was presented as \% activation compared to $\mathrm{H}_{2} \mathrm{O}_{2}$ (positive control). To evaluate the permeability of the Caco-2 monolayer, cells were treated with either vehicle (media) or different concentrations of PM and (B) transepithelial electrical resistance (TEER) was measured over time. (C) TEER values compared to control (as percent control) at 2 hours are shown. (D) We also measured the apparent permeability co-efficient (Papp) of fluorescein sulfonic acid (FSA) in the apical to basolateral direction across the Caco-2 cells. (E) Percent change in Papp values at 2 hours is shown. (P < 0.05 *PM compared with PBS, **EUK-134 compared with vehicle, $n \geq 4$ ). 
A

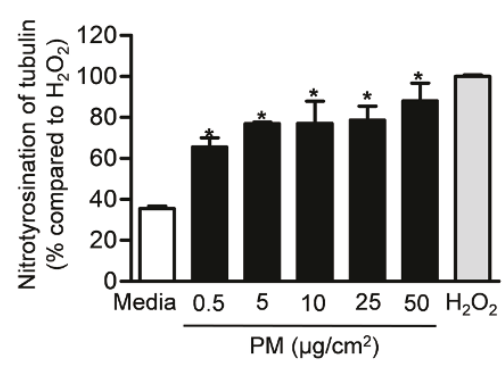

B

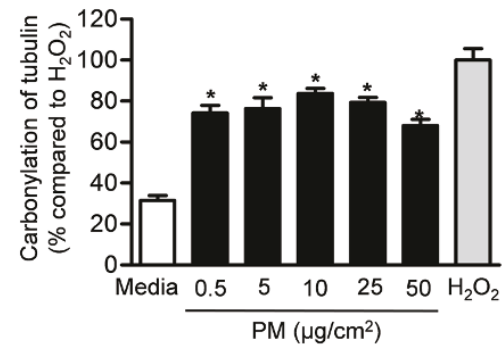

C
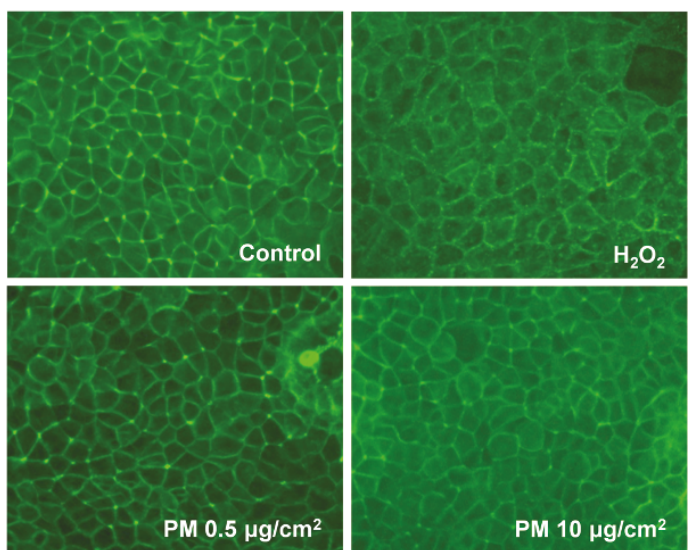

PM $25 \mu \mathrm{g} / \mathrm{cm}^{2}$

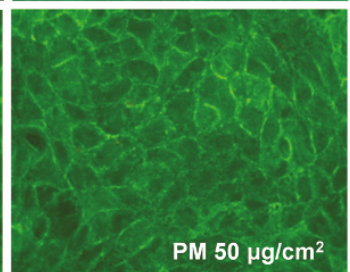

Figure 4 Exposure to particulate matter causes nitration and oxidation of tubulin and disruption of tight junctions in intestinal cell monolayers. The effect of PM on tubulin (A) nitration (nitrotyrosination) and (B) oxidation (carbonylation) in Caco-2 cell monolayers are shown. $\mathrm{H}_{2} \mathrm{O}_{2}(0.5 \mathrm{mM})$ was used as a positive control. (C) Images from high-resolution laser scanning confocal microscopic evaluation of intestinal cell monolayers stained for F-actin are shown.

small bowel tissue was altered in the PM compared with the PBS treated mice (Figure 7F).

\section{Discussion}

Exposure to air pollution is associated with well-known health effects on the cardiovascular and respiratory systems [54-56]. While less known, there also are several

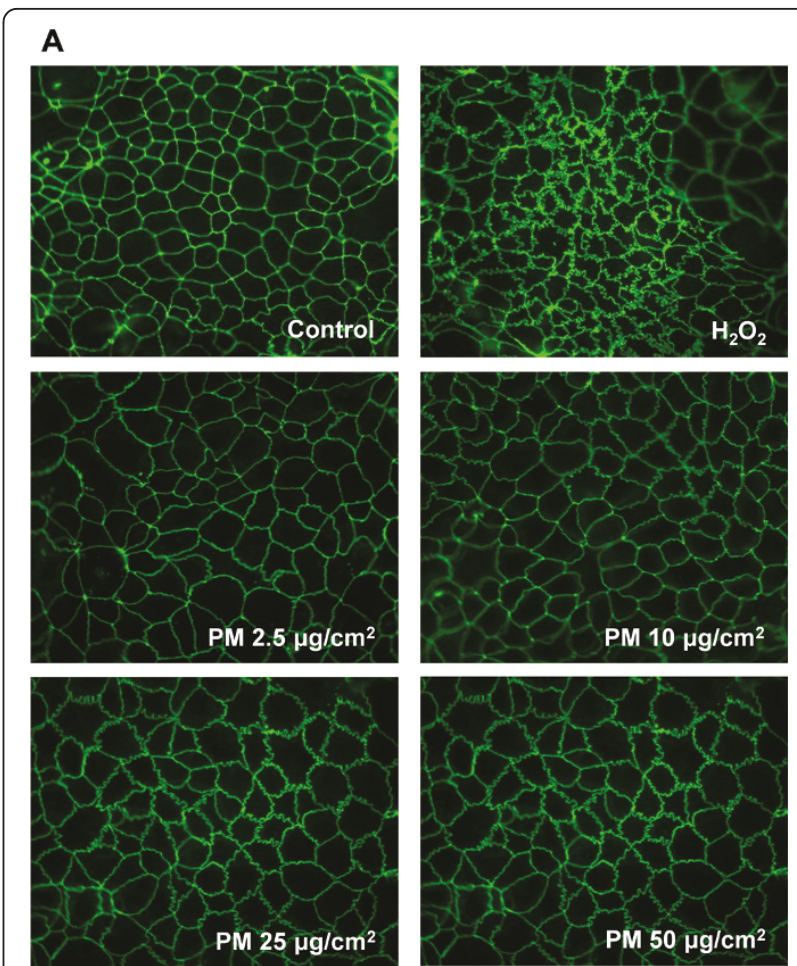

B

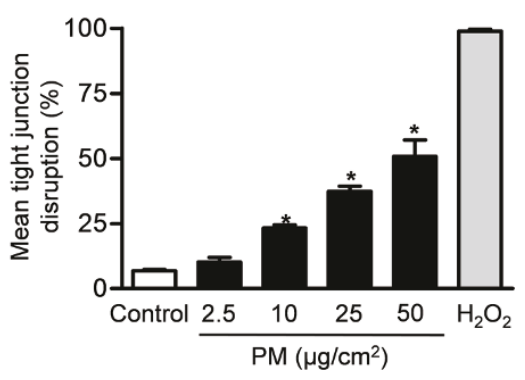

Figure 5 Exposure of monolayers of Caco-2 cells to PM causes increased permeability and disruption of tight junctions. Caco2 cells were treated with either PBS (vehicle) or different concentrations of PM and we (A) stained the cell monolayers for ZO-1, a tight junction protein and (B) measured mean tight junction disruption Intestinal sections from the animals were subjected to a blinded analysis of tight junction disruption.

Representative images from 4 independent experiments are shown and each bar represents the mean of 20 observations.

reports linking exposure to air pollution to adverse health effects in the GI tract [12-19]. Consistent with our findings in lung epithelial cells, we observed that Caco- 2 cells exposed to PM generated ROS from the mitochondria, which were required for the activation of $\mathrm{NF}-\kappa \mathrm{B}$ and the development of apoptotic cell death in vitro. In confluent monolayers of Caco-2 cells, we found that PM reduced the TER of the monolayer and caused disruption of the architecture of the tight junctions. In mice exposed to PM by oral gavage, we found evidence of increased IL- 6 transcription, disruption of small 


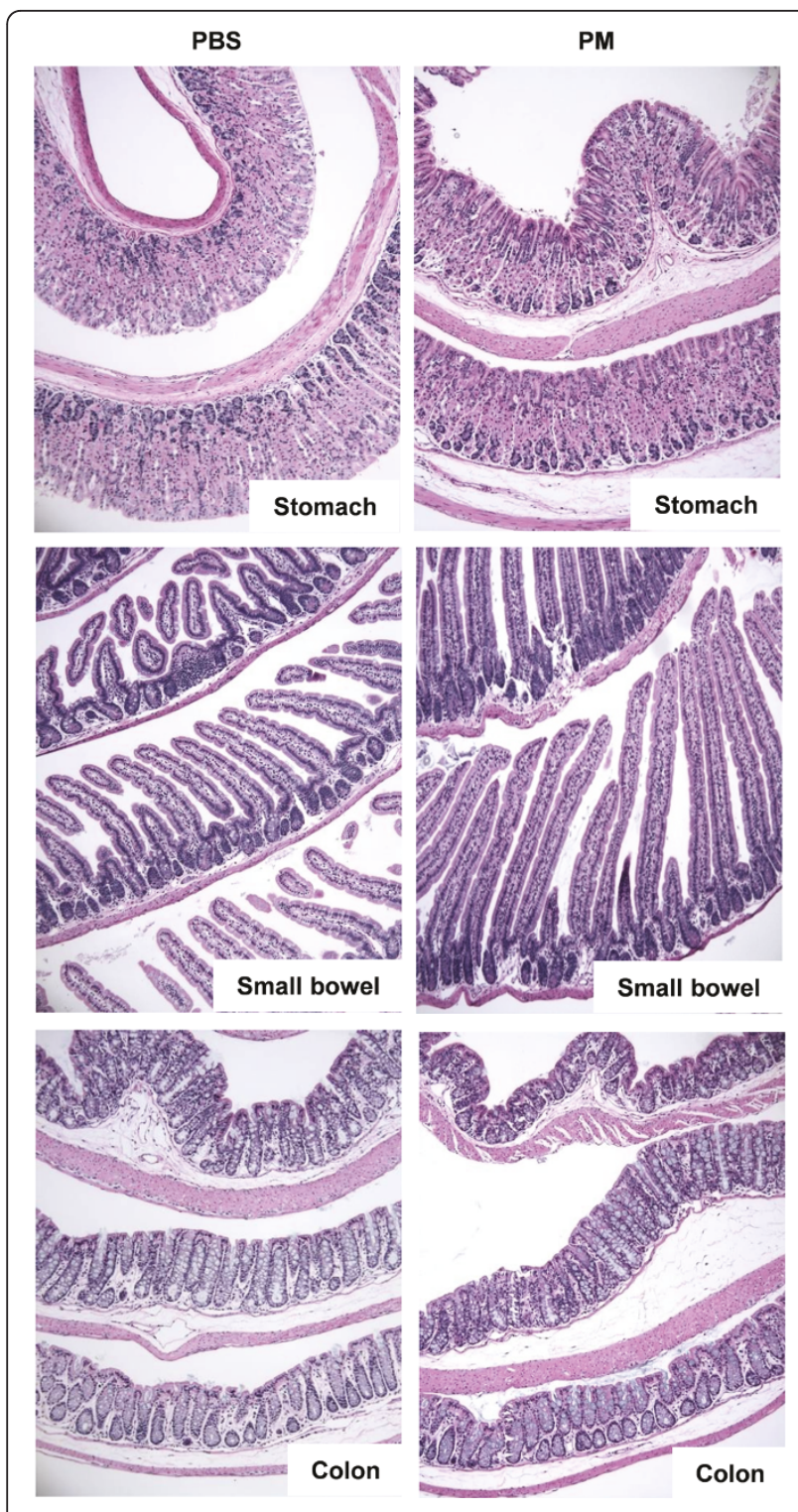

Figure 6 Exposure to PM does not cause histologic changes in gastric, small bowel and colonic mucosa at $\mathbf{2 4}$ or $\mathbf{4 8}$ hours. Wild-type cells were treated with either PBS (vehicle) or PM via gastric gavage and histology (H\&E staining) of gastric, small bowel and colonic tissue was evaluated 48 hours after exposure. Representative photomicroographs from a total of 5 animals/ treatment group are shown ( $\times 100$ magnification).

bowel tight junctions, increased numbers of TUNEL positive nuclei and increased gut permeability to FITC labeled dextran.

We found that colonic epithelial cells generate significant amounts of mitochondrially derived ROS and undergo apoptosis in response to PM exposure in vitro. Cells depleted of mitochondrial DNA ( $\rho^{0}$ Caco- 2 cells) were resistant to PM induced apoptosis. $\rho^{0}$ cells lack the 13 proteins encoded in the mitochondrial genome, which are required for normal electron transport. As a result, these cells are deficient in oxidative phosphorylation and cannot produce mitochondrial ROS. However, as most of the mitochondrial proteome is encoded by nuclear genes, these cells still contain mitochondria, maintain a mitochondrial membrane potential supported by glycolysis and undergo apoptosis normally. We reported a similar dependence of PM-induced signaling and apoptosis in alveolar epithelial cells and other investigators have highlighted the importance of mitochondrially derived ROS in the cellular response to PM $[22,37,51]$. Inflammation the GI tract during diseases such as inflammatory bowel disease is associated with increased local ROS generation and activation of NF- $\kappa \mathrm{B}$ [57-61]. We observed that the administration of PM to Caco-2 cells resulted in the oxidant dependent activation of NF- $\kappa \mathrm{B}$. The importance of these findings is highlighted by our observation that the administration of PM by oral gavage increased the transcription of an NF$\kappa \mathrm{B}$ target gene IL- 6 in the small bowel and colon.

We observed that the administration of PM to Caco-2 monolayers reduced the transepithelial resistance of the monolayers and caused a disruption in the organization of the tight junctions. In vivo, the administration of PM was associated with decreased transcription of the tight junction proteins $\mathrm{ZO}-1$ and occludin and histologic evidence of alterations in tight junction structure. There was also an increase in the number of apoptotic cells in the small bowel from these animals. Our data do not allow us to determine whether PM-induced alterations in tight junctions, apoptosis or other mechanisms are responsible for the resulting increase in gut permeability. However, this finding is important as chances in gut permeability are thought to play a pathogenic role in many gastrointestinal disorders including alcoholic liver disease, inflammatory bowel disease and celiac disease $[57,61,62]$.

While the lungs are the primary organs exposed to ambient PM; a significant portion of PM exposure can be deposited in the upper airway and also get access to the GI tract via direct entrance due to swallowing of air or indirectly via swallowing of the PM deposited in the upper airway. Furthermore, most of the inhaled PM is transported via mucociliary system from the lung to the upper airway and then swallowed. Our data support the recent reports, which showed an epidemiologic link between acute, short-term exposure to air pollution and inflammation in the gut. We speculate that PM-induced ROS generation, NF- $\kappa \mathrm{B}$ activation and activation of inflammation may be responsible for exacerbations of inflammatory conditions in the gut such as inflammatory bowel disease.

Urban PM is a complex mixture of solid and particles that primarily are formed during the combustion of 


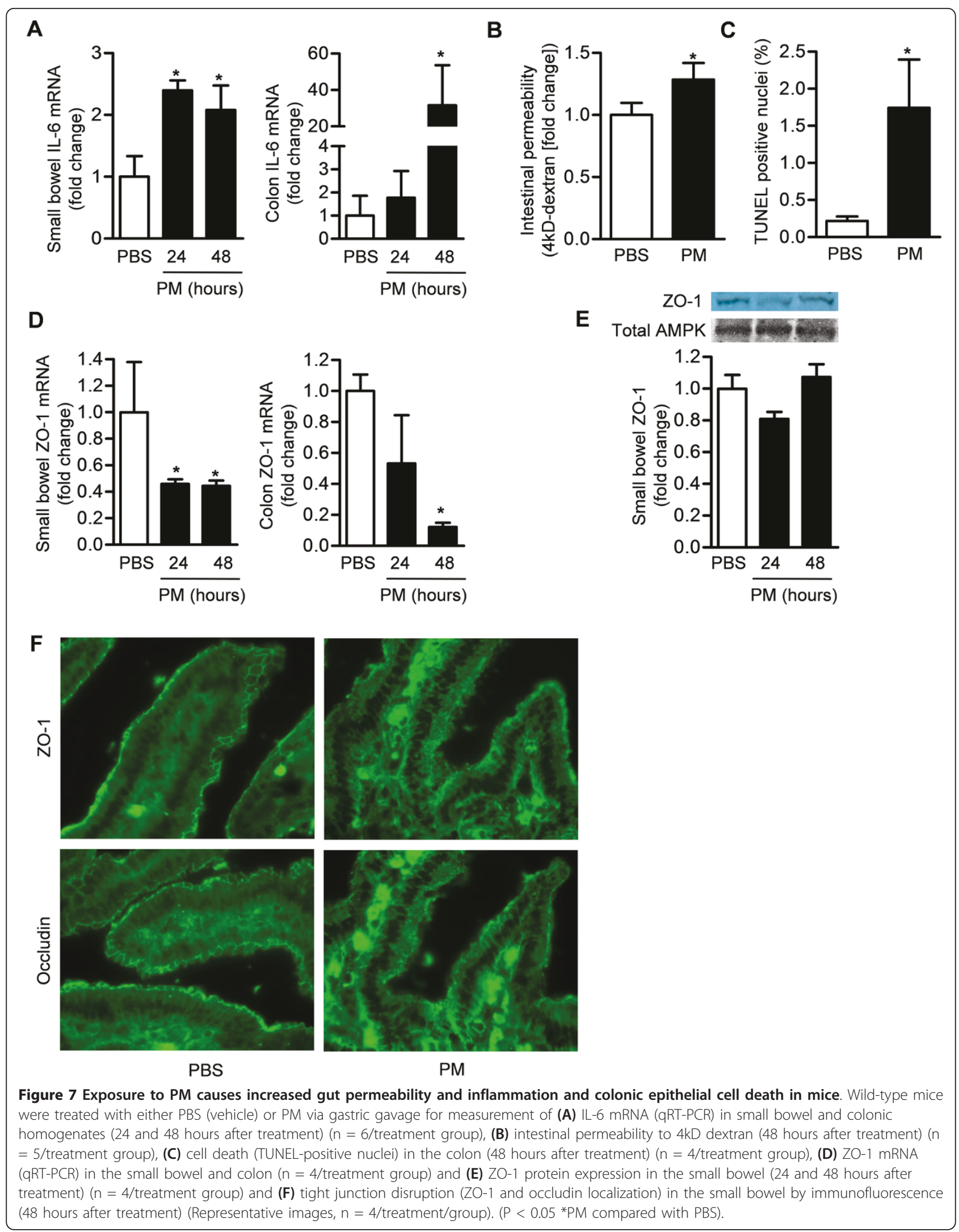


fossil fuels [63,62]. As the carbon core of the particle cools, organic components (including quinones) and transition metals (including iron and vanadium) condense on the surface of the particles. The resulting particles are composed of a carbonaceous core, organic components, sulfate, nitrate, ammonium, crustal material and transition metals such as iron or vanadium. Organic constituents in the particles, particularly quinones, can undergo single electron transfer reactions with intracellular electron acceptors, creating the opportunity for the transfer of an electron to molecular oxygen to form a superoxide radical. In the presence of a transition metal, the superoxide anion can be converted to a hydroxyl radical through Fenton chemistry [63-67]. In addition, sulfates and nitrates may combine with water to form acids which may modulate their toxicity.

An important limitation of our study is the dose of PM that we employed for our in vivo experiments. PM enters the lung via inhalation and larger particles are deposited in the oropharynx and large airways, while smaller particles gain access to the distal airspaces. A very small fraction of PM may gains access to the systemic circulation and affect systemic organs including the gut. Semmler-Benke followed the fate of iridium labeled carbon black nanoparticles administered via inhalation to rats for 6 months after the exposure. Most of the particles (> 90\%) were taken up by alveolar macrophages, cleared by mucociliary mechanisms and excreted in the feces [21]. Because the GI tract is also exposed to PM deposited in the oropharynx, PM that has sedimented on unwashed fruits and vegetables and PM contained in swallowed air, the total dose of PM to which the gut is exposed is likely at least as large as that seen by the lung. However, the more rapid transit time of the mucous layer over the gut compared with the lung mucosa may decrease the concentration of PM to which the gut is exposed at any given time. Furthermore, the administration of PM may alter the transit time of material through the gut.

In 2002, the U.S. EPA reported a range of maximal city PM concentrations between 26 and $534 \mu \mathrm{g} / \mathrm{m}^{3}$ [54]. Many large cities in the world have much higher levels of PM with annual averages of 200 to $600 \mu \mathrm{g} / \mathrm{m}^{3}$ and peak concentrations frequently exceeding $1000 \mu \mathrm{g} / \mathrm{m}^{3}$ [68]. Using the highest value in U.S. and assuming a minute ventilation of $6 \mathrm{~L} / \mathrm{min}\left(\sim 8.6 \mathrm{~m}^{3}\right.$ over 24 hours $)$ for a healthy adult at rest, the total dose of PM inhaled over 24 hours would be 4,614 $\mu \mathrm{g}$. However, in other "mega cities" of the world, the daily inhaled dose of particles may be as high as 20,000 $\mu \mathrm{g}[68,69]$. Exposure of a mouse (with a minute ventilation of $35-50 \mathrm{ml} / \mathrm{min}$ ) to a daily dose of $200 \mu \mathrm{g}$ of PM corresponds to 24-30 mg of PM exposure for a human [70]. This is about 6-8 times higher than a US adult will be exposed in even the most polluted city. Further study is required to determine whether PM induces similar effects on GI function at lower levels of exposure.

\section{Conclusions}

Exposure to high doses of PM causes oxidant dependent GI epithelial cell death, disruption of tight junctional proteins, inflammation and increased permeability in the gut in vitro and in vivo. These PM-induced changes may be responsible for exacerbations of inflammatory disorders of the gut. More studies are warranted to better understand the health effects of air pollution in the GI tract.

\section{Abbreviations}

GFP: green fluorescent protein; Gl: gastrointestinal; FITC: fluorescein isothiocyanate; PBS: phosphate buffered saline; PM: particulate matter; qRTPCR: quantitative real-time PCR; ROS: reactive oxygen species; $t-\mathrm{BOOH}$ : $t$ butyl hydroperoxide; ZO-1: zonula occludens-1.

\section{Acknowledgements}

We thank Dr. Andrew J Ghio from the United States Environmental Protection Agency, Research Triangle Park, NC for providing us with PM from Washington, DC and his suggestions and careful review of our manuscript. This work was supported by NIH ES015024 (to GMM), ES 013995 (to GRSB) and 1P01HL071643 (to GMM and GRSB).

\section{Author details}

${ }^{1}$ Department of Medicine, Section of Gastroenterology and Nutrition Rush University Medical College, 1725 W Harrison Street, Chicago, IL, 60612 USA. ${ }^{2}$ Department of Medicine, Division of Pulmonary and Critical Care Medicine, Feinberg School of Medicine, Northwestern University, 240 E Huron Street, McGaw M300, Chicago, IL, 60611, USA. ${ }^{3}$ Department of Pathology, Rush University Medical College, 1725 W Harrison Street, Chicago, IL, 60612 USA.

\section{Authors' contributions}

EAM, CF, AK, GRSB and GMM: Designed research, analyzed and interpreted data and wrote the manuscript. PE, SS, DU, CF, RN, SEC, KAR, AG and GMM performed research, analyzed data and reviewed the manuscript. SJ, EAM and AK reviewed histology slides.

All authors have read and approved the final manuscript.

\section{Competing interests}

The authors declare that they have no competing interests.

Received: 12 April 2011 Accepted: 9 June 2011 Published: 9 June 2011

\section{References}

1. Downs SH, Schindler C, Liu LJ, Keidel D, Bayer-Oglesby L, Brutsche MH, Gerbase MW, Keller R, Kunzli N, Leuenberger P, Probst-Hensch NM, Tschopp JM, Zellweger JP, Rochat T, Schwartz J, Ackermann-Liebrich U, SAPALDIA Team: Reduced exposure to PM10 and attenuated age-related decline in lung function. $N$ Engl J Med 2007, 357:2338-2347.

2. Gauderman WJ, Avol E, Gilliland F, Vora H, Thomas D, Berhane K, McConnell R, Kuenzli N, Lurmann F, Rappaport E, Margolis H, Bates D, Peters J: The Effect of Air Pollution on Lung Development from 10 to 18 Years of Age. N Engl J Med 2004, 351:1057-1067.

3. Krewski D, Burnett RT, Goldberg MS, Hoover K, Siemiatycki J, Abrahamowicz M, White WH: Validation of the Harvard Six Cities Study of particulate air pollution and mortality. N Engl J Med 2004, 350:198-199.

4. McCreanor J, Cullinan P, Nieuwenhuijsen MJ, Stewart-Evans J, Malliarou E, Jarup L, Harrington R, Svartengren $M$, Han IK, Ohman-Strickland $P$, Chung KF, Zhang J: Respiratory effects of exposure to diesel traffic in persons with asthma. N Engl J Med 2007, 357:2348-2358.

5. Miller KA, Siscovick DS, Sheppard L, Shepherd K, Sullivan JH, Anderson GL, Kaufman JD: Long-Term Exposure to Air Pollution and Incidence of Cardiovascular Events in Women. N Engl J Med 2007, 356:447-458. 
6. Mills NL, Tornqvist H, Gonzalez MC, Vink E, Robinson SD, Soderberg S, Boon NA, Donaldson K, Sandstrom T, Blomberg A, Newby DE: Ischemic and Thrombotic Effects of Dilute Diesel-Exhaust Inhalation in Men with Coronary Heart Disease. N Engl J Med 2007, 357:1075-1082.

7. Pope CA III, Ezzati M, Dockery DW: Fine-Particulate Air Pollution and Life Expectancy in the United States. N Engl J Med 2009, 360:376-386.

8. Neupane B, Jerrett M, Burnett RT, Marrie T, Arain A, Loeb M: Long-Term Exposure to Ambient Air Pollution and Risk of Hospitalization with Community-acquired Pneumonia in Older Adults. Am J Respir Crit Care Med 2010, 181:47-53.

9. Baccarelli A, Martinelli I, Zanobetti A, Grillo P, Hou LF, Bertazzi PA Mannucci PM, Schwartz J: Exposure to Particulate Air Pollution and Risk of Deep Vein Thrombosis. Arch Intern Med 2008, 168:920-927.

10. Baccarelli A, Martinelli I, Pegoraro V, Melly S, Grillo P, Zanobetti A, Hou L, Bertazzi PA, Mannucci PM, Schwartz J: Living near major traffic roads and risk of deep vein thrombosis. Circulation 2009, 119:3118-3124.

11. Dales RE, Cakmak S, Vidal CB: Air Pollution and hospitalization for venous thromboembolic disease in Chile. Journal of Thrombosis and Haemostasis 2010, 9999

12. Kaplan GG, Hubbard J, Korzenik J, Sands BE, Panaccione R, Ghosh S, Wheeler AJ, Villeneuve PJ: The inflammatory bowel diseases and ambient air pollution: a novel association. Am J Gastroenterol 2010, 105:2412-2419.

13. Ananthakrishnan AN, McGinley EL, G BD, Saeian K: Air pollution and hospitalizations for inflammatory bowel disease: An ecologic analysis. Gastroenterology 2010, 138:S17-S18.

14. Kaplan GG, Dixon E, Panaccione R, Fong A, Chen L, Szyszkowicz M, Wheeler A, Maclean A, Buie WD, Leung T, Heitman SJ, Villeneuve PJ: Effect of ambient air pollution on the incidence of appendicitis. CMAJ 2009

15. Orazzo F, Nespoli L, Ito K, Tassinari D, Giardina D, Funis M, Cecchi A, Trapani C, Forgeschi G, Vignini M, Nosetti L, Pigna S, Zanobetti A: Air pollution, aeroallergens, and emergency room visits for acute respiratory diseases and gastroenteric disorders among young children in six Italian cities. Environ Health Perspect 2009, 117:1780-1785.

16. Guberan E, Usel M, Raymond L, Bolay J, Fioretta G, Puissant J: Increased risk for lung cancer and for cancer of the gastrointestinal tract among Geneva professional drivers. $\mathrm{Br}$ J Ind Med 1992, 49:337-344.

17. Gerhardsson de Verdier M, Plato N, Steineck G, Peters JM: Occupational exposures and cancer of the colon and rectum. Am J Ind Med 1992, 22:291-303.

18. Andersen A, Barlow L, Engeland A, Kjaerheim K, Lynge E, Pukkala E: Workrelated cancer in the Nordic countries. Scand J Work Environ Health 1999 25(Suppl 2):1-116.

19. Goldberg MS, Parent ME, Siemiatycki J, Desy M, Nadon L, Richardson L, Lakhani R, Latreille B, Valois MF: A case-control study of the relationship between the risk of colon cancer in men and exposures to occupational agents. Am J Ind Med 2001, 39:531-546.

20. Nel A: Atmosphere. Air pollution-related illness: effects of particles. Science 2005, 308:804-806.

21. Semmler-Behnke M, Takenaka S, Fertsch S, Wenk A, Seitz J, Mayer P, Oberdorster G, Kreyling WG: Efficient elimination of inhaled nanoparticles from the alveolar region: evidence for interstitial uptake and subsequent reentrainment onto airways epithelium. Environ Health Perspect 2007 115:728-733.

22. Urich D, Soberanes S, Burgess Z, Chiarella SE, Ghio AJ, Ridge KM, Kamp DW, Chandel NS, Mutlu GM, Budinger GR: Proapoptotic Noxa is required for particulate matter-induced cell death and lung inflammation. FASEB $J$ 2009, 23:2055-2064.

23. Ward NS, Waxman AB, Homer RJ, Mantell LL, Einarsson O, Du Y, Elias JA Interleukin-6-induced protection in hyperoxic acute lung injury. Am J Respir Cell Mol Biol 2000, 22:535-542.

24. Mutlu GM, Budinger GR, Green AA, Urich D, Soberanes S, Chiarella SE, Alheid GF, McCrimmon DR, Szleifer I, Hersam MC: Biocompatible nanoscale dispersion of single-walled carbon nanotubes minimizes in vivo pulmonary toxicity. Nano Lett 2010, 10:1664-1670.

25. Budinger GR, Mutlu GM, Eisenbart J, Fuller AC, Bellmeyer AA, Baker CM, Wilson M, Ridge K, Barrett TA, Lee WY, Chandel NS: Proapoptotic Bid is required for pulmonary fibrosis. Proc Natl Acad Sci USA 2006, 103:4604-4609.

26. Cani PD, Possemiers S, Van de Wiele T, Guiot Y, Everard A, Rottier O, Geurts L, Naslain D, Neyrinck A, Lambert DM, Muccioli GG, Delzenne NM: Changes in gut microbiota control inflammation in obese mice through a mechanism involving GLP-2-driven improvement of gut permeability. Gut 2009, 58:1091-1103.

27. Cani PD, Bibiloni R, Knauf C, Waget A, Neyrinck AM, Delzenne NM, Burcelin R: Changes in gut microbiota control metabolic endotoxemiainduced inflammation in high-fat diet-induced obesity and diabetes in mice. Diabetes 2008, 57:1470-1481.

28. Erlejman AG, Fraga CG, Oteiza Pl: Procyanidins protect Caco-2 cells from bile acid- and oxidant-induced damage. Free Radic Biol Med 2006, 41:1247-1256.

29. Buzza MS, Netzel-Arnett S, Shea-Donohue T, Zhao A, Lin CY, List K, Szabo R, Fasano A, Bugge TH, Antalis TM: Membrane-anchored serine protease matriptase regulates epithelial barrier formation and permeability in the intestine. Proc Natl Acad Sci USA 2010, 107:4200-4205.

30. Narai A, Arai S, Shimizu M: Rapid decrease in transepithelial electrical resistance of human intestinal Caco- 2 cell monolayers by cytotoxic membrane perturbents. Toxicol In Vitro 1997, 11:347-354.

31. Turner JR, Angle JM, Black ED, Joyal JL, Sacks DB, Madara JL: PKC dependent regulation of transepithelial resistance: roles of MLC and MLC kinase. Am J Physiol 1999, 277:C554-562.

32. Turner JR, Rill BK, Carlson SL, Carnes D, Kerner R, Mrsny RJ, Madara JL: Physiological regulation of epithelial tight junctions is associated with myosin light-chain phosphorylation. Am J Physiol 1997, 273 C1378-1385.

33. Hubatsch I, Ragnarsson EG, Artursson P: Determination of drug permeability and prediction of drug absorption in Caco-2 monolayers. Nat Protoc 2007, 2:2111-2119.

34. Biganzoli E, Cavenaghi LA, Rossi R, Brunati MC, Nolli ML: Use of a Caco-2 cell culture model for the characterization of intestinal absorption of antibiotics. Farmaco 1999, 54:594-599.

35. Banan A, Zhang LJ, Shaikh M, Fields JZ, Farhadi A, Keshavarzian A: Key role of PLC-gamma in EGF protection of epithelial barrier against iNOS upregulation and F-actin nitration and disassembly. Am J Physiol Cell Physiol 2003, 285:C977-993

36. Banan A, Zhang Y, Losurdo J, Keshavarzian A: Carbonylation and disassembly of the F-actin cytoskeleton in oxidant induced barrier dysfunction and its prevention by epidermal growth factor and transforming growth factor alpha in a human colonic cell line. Gut 2000, 46:830-837.

37. Soberanes S, Urich D, Baker CM, Burgess Z, Chiarella SE, Bell EL, Ghio AJ, De Vizcaya-Ruiz A, Liu J, Ridge KM, Kamp DW, Chandel NS, Schumacker PT, Mutlu GM, Budinger GR: Mitochondrial complex III-generated oxidants activate ASK1 and JNK to induce alveolar epithelial cell death following exposure to particulate matter air pollution. J Biol Chem 2009, 284:2176-2186

38. Guzy RD, Sharma B, Bell E, Chandel NS, Schumacker PT: Loss of the SdhB, but Not the SdhA, subunit of complex II triggers reactive oxygen species-dependent hypoxia-inducible factor activation and tumorigenesis. Mol Cell Biol 2008, 28:718-731.

39. Budinger GR, Tso M, McClintock DS, Dean DA, Sznajder Jl, Chandel NS: Hyperoxia-induced apoptosis does not require mitochondrial reactive oxygen species and is regulated by $\mathrm{Bcl}-2$ proteins. J Biol Chem 2002, 277:15654-15660.

40. Chandel NS, Schumacker PT: Cells depleted of mitochondrial DNA (rho0) yield insight into physiological mechanisms. FEBS Lett 1999, 454:173-176.

41. King MP, Attardi G: Human cells lacking mtDNA: repopulation with exogenous mitochondria by complementation. Science 1989, 246:500-503.

42. Dooley CT, Dore TM, Hanson GT, Jackson WC, Remington SJ, Tsien RY: Imaging dynamic redox changes in mammalian cells with green fluorescent protein indicators. J Biol Chem 2004, 279:22284-22293.

43. Hanson GT, Aggeler R, Oglesbee D, Cannon M, Capaldi RA, Tsien RY, Remington SJ: Investigating mitochondrial redox potential with redoxsensitive green fluorescent protein indicators. J Biol Chem 2004, 279:13044-13053.

44. Buccellato LJ, Tso M, Akinci Ol, Chandel NS, Budinger GR: Reactive oxygen species are required for hyperoxia-induced Bax activation and cell death in alveolar epithelial cells. J Biol Chem 2004, 279:6753-6760.

45. Melov S, Ravenscroft J, Malik S, Gill MS, Walker DW, Clayton PE, Wallace DC, Malfroy B, Doctrow SR, Lithgow GJ: Extension of life-span with superoxide dismutase/catalase mimetics. Science 2000, 289:1567-1569.

46. Banan A, Zhang $L$, Shaikh M, Fields JZ, Farhadi A, Keshavarzian A: Novel effect of NF-kappaB activation: carbonylation and nitration injury to 
cytoskeleton and disruption of monolayer barrier in intestinal epithelium. Am J Physiol Cell Physiol 2004, 287:C1139-1151.

47. Banan A, Zhang L, Farhadi A, Fields JZ, Shaikh M, Forsyth CB, Choudhary S, Keshavarzian A: Critical role of the atypical \{lambda\} isoform of protein kinase C (PKC-\{lambda\}) in oxidant-induced disruption of the microtubule cytoskeleton and barrier function of intestinal epithelium. J Pharmacol Exp Ther 2005, 312:458-471.

48. Banan A, Zhang L, Farhadi A, Fields JZ, Shaikh M, Keshavarzian A: PKCbeta1 isoform activation is required for EGF-induced NF-kappaB inactivation and IkappaBalpha stabilization and protection of F-actin assembly and barrier function in enterocyte monolayers. Am J Physiol Cell Physiol 2004, 286:C723-738

49. Renard P, Ernest I, Houbion A, Art M, Le Calvez H, Raes M, Remacle J: Development of a sensitive multi-well colorimetric assay for active NFkappaB. Nucleic Acids Res 2001, 29:E21.

50. Banan A, Choudhary S, Zhang Y, Fields JZ, Keshavarzian A: Ethanol-induced barrier dysfunction and its prevention by growth factors in human intestinal monolayers: evidence for oxidative and cytoskeletal mechanisms. J Pharmacol Exp Ther 1999, 291:1075-1085.

51. Mutlu GM, Snyder C, Bellmeyer A, Wang H, Hawkins K, Soberanes S, Welch LC, Ghio AJ, Chandel NS, Kamp D, Sznajder Jl, Budinger GR: Airborne particulate matter inhibits alveolar fluid reabsorption in mice via oxidant generation. Am J Respir Cell Mol Biol 2006, 34:670-676.

52. Barnes PJ, Karin M: Nuclear factor-kappaB: a pivotal transcription factor in chronic inflammatory diseases. N Engl J Med 1997, 336:1066-1071.

53. Mutlu E, Keshavarzian A, Engen P, Forsyth CB, Sikaroodi M, Gillevet P: Intestinal dysbiosis: a possible mechanism of alcohol-induced endotoxemia and alcoholic steatohepatitis in rats. Alcohol Clin Exp Res 2009, 33:1836-1846.

54. Brook RD, Franklin B, Cascio W, Hong Y, Howard G, Lipsett M, Luepker R, Mittleman M, Samet J, Smith SC Jr, Tager I: Air pollution and cardiovascular disease: a statement for healthcare professionals from the Expert Panel on Population and Prevention Science of the American Heart Association. Circulation 2004, 109:2655-2671.

55. Mutlu GM, Green D, Bellmeyer A, Baker CM, Burgess Z, Rajamannan N, Christman JW, Foiles N, Kamp DW, Ghio AJ, Chandel NS, Dean DA, Sznajder Jl, Budinger GR: Ambient particulate matter accelerates coagulation via an IL-6-dependent pathway. J Clin Invest 2007, 117:2952-2961

56. Peters A, von Klot S, Heier M, Trentinaglia I, Hormann A, Wichmann HE, Lowel $\mathrm{H}$ : Exposure to traffic and the onset of myocardial infarction. $N$ Engl J Med 2004, 351:1721-1730.

57. McKenzie SJ, Baker MS, Buffinton GD, Doe WF: Evidence of oxidantinduced injury to epithelial cells during inflammatory bowel disease. J Clin Invest 1996, 98:136-141

58. Banan A, Farhadi A, Fields JZ, Mutlu E, Zhang L, Keshavarzian A: Evidence that nuclear factor-kappa B activation is critical in oxidant-induced disruption of the microtubule cytoskeleton and barrier integrity and that its inactivation is essential in epidermal growth factor-mediated protection of the monolayers of intestinal epithelia. J Pharmacol Exp Ther 2003, 306:13-28.

59. Rogler G, Brand K, Vogl D, Page S, Hofmeister R, Andus T, Knuechel R, Baeuerle PA, Scholmerich J, Gross V: Nuclear factor kappaB is activated in macrophages and epithelial cells of inflamed intestinal mucosa. Gastroenterology 1998, 115:357-369.

60. Schreiber S, Nikolaus S, Hampe J: Activation of nuclear factor kappa B inflammatory bowel disease. Gut 1998, 42:477-484.

61. Keshavarzian A, Banan A, Farhadi A, Komanduri S, Mutlu E, Zhang Y, Fields JZ: Increases in free radicals and cytoskeletal protein oxidation and nitration in the colon of patients with inflammatory bowel disease. Gut 2003, 52:720-728.

62. Lammers KM, Lu R, Brownley J, Lu B, Gerard C, Thomas K, Rallabhandi P, Shea-Donohue T, Tamiz A, Alkan S, Netzel-Arnett S, Antalis T, Vogel SN, Fasano A: Gliadin induces an increase in intestinal permeability and zonulin release by binding to the chemokine receptor CXCR3. Gastroenterology 2008, 135:194-204, e193.

63. Kumagai Y, Arimoto T, Shinyashiki M, Shimojo N, Nakai Y, Yoshikawa T, Sagai M: Generation of reactive oxygen species during interaction of diesel exhaust particle components with NADPH-cytochrome P450 reductase and involvement of the bioactivation in the DNA damage. Free Radic Biol Med 1997, 22:479-487.
64. Xia T, Korge P, Weiss JN, Li N, Venkatesen Ml, Sioutas C, Nel A: Quinones and aromatic chemical compounds in particulate matter induce mitochondrial dysfunction: implications for ultrafine particle toxicity. Environ Health Perspect 2004, 112:1347-1358.

65. Hiura TS, Kaszubowski MP, Li N, Nel AE: Chemicals in diesel exhaust particles generate reactive oxygen radicals and induce apoptosis in macrophages. J Immunol 1999, 163:5582-5591.

66. Karczewski JM, Peters JG, Noordhoek J: Prevention of oxidant-induced cell death in Caco-2 colon carcinoma cells after inhibition of poly(ADPribose) polymerase and $\mathrm{Ca} 2+$ chelation: involvement of a common mechanism. Biochem Pharmacol 1999, 57:19-26.

67. Ferruzza S, Scacchi M, Scarino ML, Sambuy Y: Iron and copper alter tight junction permeability in human intestinal Caco-2 cells by distinct mechanisms. Toxicol In Vitro 2002, 16:399-404.

68. Mage D, Ozolins G, Peterson P, Webster A, Orthofer RW, Gwynne M: Urban air pollution in megacities of the world. Atmospheric Environment 1996, 30:681-686.

69. Benchmarking Urban Air Quality Management and Practice in Major and Mega Cities of Asia. [http://www.unep.org/PDF/ APMA_Benchmarking_report.pdf].

70. de Hennezel L, Debarre S, Ramisse F, Delamanche S, Harf A, Alonso JM, Calvet JH: Plethysmography for the assessment of pneumococcal pneumonia and passive immunotherapy in a mouse model. Eur Respir $\lrcorner$ 2001, 17:94-99.

doi:10.1186/1743-8977-8-19

Cite this article as: Mutlu et al.: Particulate matter air pollution causes oxidant-mediated increase in gut permeability in mice. Particle and Fibre Toxicology 2011 8:19.

\section{Submit your next manuscript to BioMed Central and take full advantage of:}

- Convenient online submission

- Thorough peer review

- No space constraints or color figure charges

- Immediate publication on acceptance

- Inclusion in PubMed, CAS, Scopus and Google Scholar

- Research which is freely available for redistribution

Submit your manuscript at www.biomedcentral.com/submit
C BioMed Central 